\title{
The Impact of Extensive Reading Programs on the Pronunciation Accuracy of EFL Learners at Basic Levels
}

\author{
Elham Malmeer \\ Department of English Teaching, Science and Research Branch, Islamic Azad University, Kermanshah, Iran \\ Seyed Mahdi Araghi \\ Department of English Language Teaching, Payam Noor University, Tabriz, Iran
}

\begin{abstract}
This experimental study aimed to investigate the effect of extensive reading on the pronunciation ability of EFL learners at basic levels. The proposed hypothesis predicted that the use of an extensive reading program, such as Uninterrupted Sustained Silent Reading (USSR), Drop Everything and Read (DEAR), or the Book Flood Approach, while nurturing a lifelong reading habit, leads to fossilization of incorrect pronunciations at basic levels. To this end,100 EFL students attending English language courses at Azad University of Kermanshah were selected using convenient sampling. Pretests were administered before the application of experimental and control treatments. The equivalence of the groups was provided by random assignment of subjects to experimental and control treatments. Also a post test was administered after the treatment. Both quantitative and qualitative methods were used for data analyses. The mean test scores of both groups was subjected to the test of statistical significance which was a t-test. Based on the use of descriptive and inferential statistics, it was concluded that the use of extensive reading programs leads to the fossilization of incorrect pronunciations at basic levels among EFL learners.
\end{abstract}

Index Terms-extensive reading, intensive reading, SLA, pronunciation

\section{INTRODUCTION}

In many second or foreign language teaching situations, reading receives a special focus. There are many reasons to this, chief among them are the pedagogical purposes served by the written texts, students' goals and teachers' emphasis. Students want to read for information and pleasure, for their career and for educational purposes. Appropriate reading materials also provide good models for writing as well as chances to introduce new topics, to create discussion opportunities, and to study different skills and sub skills of the language. In other words, reading is an invaluable skill for both students and teachers. In fact, beyond powerful gains in language proficiency, reading offers more. It offers a richer understanding of the worlds around us. It represents a lifelong habit, a habit that brings with it the power and wealth that language offers in such large quantities. Motivating students for reading extensively and helping them in how to do so will help learners in their reading proficiency.

A number of advances have been made in research on reading, both in first and second language. Richards (2002) states that although the advances in the first language contexts have led to a number of improvement in reading instruction, the corresponding research in second language contexts has not made as much headway (p.273).In fact, despite improvements that have been achieved in research on second language reading, there are still many problems to be addressed before research findings can be applied in the classroom. The most crucial problem, Grabe (1995) maintains, lies in the fact that research in second language reading tends to be short term and less programmatic. Therefore, we don't have enough evidence to enable us to say with confidence what works best in which second language context. Richards (2002, p.274) states that "if second language reading research is to have any significant impact on instruction, it is imperative that we encourage more systematic and programmatic research studies that examine aspects of reading instruction under a variety of contexts and over a longer period of time. Results of longitudinal studies of this nature are likely to reduce the gap between theory and practice.

Dilemmas for second language reading instruction

William Grabe, (1995) believes that "there are fundamental dilemmas for L2 reading which need to be discussed, explored and resolved" (p.3). He states that the most obvious dilemma for second language instruction is the many different contexts for second language reading instruction. The second dilemma derives from U.S- based generative linguistic foundation of most research in SLA and the subsequence irrelevance of much of SLA for L2 reading research. He believes that readers can improve their reading comprehension and inferencing ability through being familiar with formal aspects of language and genres structures. He also emphasized the role of having access to large vocabulary knowledge not only for enhancing reading ability but also for all language skills. In addition, social context of the 
students' home environment, not enough emphasis on reading strategies and the uncritical acceptance of schema theory represent other dilemmas for language reading instruction.

\section{Implications of reading strategy research}

Reading strategies can be defined as "plans for solving problems encountered in constructing meaning" (Duffy, 1993, p.323). A number of reading strategies and techniques have been developed by researchers in the field of second language teaching ranging from bottom up vocabulary strategies to more comprehensive actions such as connecting what is being read to the readers' background knowledge. However, many applied linguists, today, are concerned with describing language pedagogy that is based on principled understanding of second language research. Brown (1992) has suggested a set of teaching/learning principles to which any good language pedagogy should conform. "These principles include providing a rich linguistic environment, respecting and capitalizing on learners' contribution to the learning process, and emphasizing fluency over accuracy"(Richards.2002)

\section{Types of reading}

Generally, there are two types of reading. Extensive reading(ER) is different from intensive reading (IR). It is important to note that these two approaches to teaching reading -intensive and extensive- should not be seen as two different ways of reading which are in opposition, since both have complementary purposes. In intensive reading, students work with short texts with close guidance and help of a teacher in order to understand every part of the reading in detail, improve reading skills, and develop vocabulary and grammar knowledge. According to Carrell and Carson(1997,pp.49-50) "extensive reading... generally involves rapid reading of large quantities of material or longer reading(e.g. whole book) for general understanding with the focus generally on the meaning of what is being read than on the language". Renandya and Jacobs (1999, p.1) state that "Extensive Reading(ER) with its emphasis on encouraging learners to read self selected large amount of meaningful language, fits well with current principles for good second and foreign language pedagogy". Davis (1995, p.329) believes that "Students will compete against themselves and it's up to the teacher to provide motivation and monitoring to ensure that the maximum number of books is being read in the time available". While different ER programs come under different names, they all have a common purpose: learners read large quantity of books and materials in an environment that nurtures a lifelong habit.

Although extensive reading is not new, many students are not aware of the possible advantages that it can have for improving their ability in second language. According to Day\& Bamford (1998) one of the most important reasons is that many teachers believe that intensive reading alone will produce good, fluent readers. Extensive reading is seen as offering many advantages (Day\& Bamford, 1998; Krashen, 1993; Nation, 1997) some of which are as include:1-better reading and writing skill 2-positive attitude toward the process of learning 3- more enjoyment in reading 4- better knowledge of the world 5- improved reading habits 6- enhanced language proficiency

While the truth of none of these advantages is questionable, unfortunately, nothing has been said about the impact of extensive reading on students' pronunciation. Unfortunately, absence of systematic instruction for pronunciation at basic levels may result in Fossilization which is "a process in which incorrect linguistic features become a permanent part of the way a person speaks or writes a language. Aspects of pronunciation, vocabulary usage and grammar may become fixed or fossilized in second or foreign language learning."(Richards, Jack C \&Schmidt, Richards, 2002). As the learners' focus on getting the meaning increases they are less likely to pay intensive attention to the way they pronounce new words they encounter while reading.

\section{Teaching Pronunciation}

Over the past half century, pronunciation has received different degrees of emphases by different language teaching methods and there are many factors affecting the acquisition of pronunciation. Researchers and practitioners' have different views to the practicality of teaching pronunciation to the second or foreign language learners. Some believe that the help provided to the learners on their pronunciation is of no value or at most a little change may happen because the learners follow their own pattern of developing their pronunciation accuracy. other theorist believe that teaching pronunciation is of great help as it leads into accurate pronunciation as well as enhancing learners attitude toward pronunciation development(Richards and Renandya, 2002, p.176).Julie Herbert, (1993) outlined four steps with which teachers can introduce learners to some of the prosodic features of L2.she believed this can be done with low-level learners through "setting the context, diagnosing learners spoken English, selecting the content, and incorporating phonology into ESL lessons".

\section{Empirical Studies}

There is a large number of researches about the role of extensive reading in first language, for which there are different names like "pleasure reading," "sustained silent reading" [SSR], or "uninterrupted sustained silent reading" [USSR] (see research cited in Krashen, 1985, p. 91; Krashen, 1988; Vaughan, 1982, p. 69). This corresponds more or less to FL/ESL/EFL extensive reading (see Bamford, 1987; Dubin \& Olshtain, 1977, pp. 77ff; Grellet, 1981, p. 4; Krashen, 1982, pp. 164-167, 1985, pp. 89-94; Olshtain, 1976, pp. 39ff). However, in a research on the literature of FL extensive reading, Brumfit (1978) claimed that "the role of the extensive reader in the curriculum has been surprisingly little studied" (p. 178); and "the discussion of teaching methods is conducted at a low theoretical level if it is conducted at all" (p. 179). MacLean's (1985) bibliography of reading in a second or foreign language lists only four items on extensive reading. None of the 99 items in ERIC computer search \#200, "Reading Strategies in Second Languages" (October 1987) is about extensive reading. Swaffar's (1988) survey of FL reading research mentions only one article on 
extensive reading out of 221 items. Oddly enough, one conclusion Swaffar reaches after examining 220 items not about extensive reading is that teachers in the future "may well be asking students to do extensive reading on a longer text or in a particular field of study" (p. 141).

Also a number of scholars have investigated the influence of extensive reading on different skills in second language learning. In a study, Chao and Krashen (1994) concluded that extensive reading results in an increase in reading proficiency, oral fluency, vocabulary knowledge, attitude and motivation. Moreover, Pitts, White, \& Krashen, (1989) conducted a research on ESL adults in the United States and concluded that extensive reading resulted in an increase in vocabulary knowledge as well as reading comprehension. Another study conducted by Elley \& Mangubhai (1981) on EFL primary students in Fiji showed that extensive reading resulted in an increases in reading proficiency, general language proficiency including listening and writing, and an increase in attitude and motivation.

The relationship between extensive reading and grammar has also been investigated by Aaron Mac Coon, (2011). He stated that "the chief contention advanced in objection to a comprehensive grammar course was, naturally, that it absorbs too much time that ought to be occupied in extensive reading. In addition, some scholars have conducted research on the attitude of students toward extensive reading. As an example Dupuy, Beatrice, C. (1997) in a article titled 'Voices from the classroom: intermediate-level French students favor extensive reading over grammar and give their reasons' surveyed 49 intermediate-level French-as-a-Foreign-Language college students to determine whether they preferred extensive reading or grammar instruction for language acquisition and practice, and why. Students overwhelmingly preferred reading as more pleasurable and more beneficial for language acquisition. They considered grammar instruction dull with small, short-lived effects. Also, Thomas N. Robb and Bernard Susser, (1989), studied extensive reading vs. skills building in an EFL context. They concluded that extensive reading may be at least as effective as skills-building with the important advantage that it is more interesting for learners.

\section{Purpose of the study}

While countless advantages of using an extensive reading program in a language course have been outlined by different scholars, almost nothing has been said about the impact of reading large quantity of materials extensively on the pronunciation of the students at basic levels and that it may have a detrimental effect on their pronunciation as far as they may be encouraged to pronounce new words incorrectly which in turn leads to permanent fossilization of these forms. To this end and to fill the stated gap, this study aimed at investigating the relationship between an extensive reading treatment course with pronunciation accuracy of the EFL learners at low-levels.

The following research questions were raised in this study:

1. Does the introduction of an extensive reading course have any impact on the learners' pronunciation ability?

\section{METHOD}

\section{A. Participants}

The participants in this study were 100 EFL learners in Azad University in Kermanshah, Iran. The participants, who were within the age range of 18-30, consisted of 55 females and450 males. The participants, who were all at basic levels regarding their mastery of English language, were studying English for general purpose. They were all studying Active Reading, Book 1 Written by Neil J. Anderson (2007) which was prescribed by the university decision makers. The classes met two times a week for 25 sessions.

\section{B. Materials and Instruments}

Different reading materials were used in this study. The book entitled 'Active Skills for Reading, Book 1' written by Neil J. Anderson (2007) was the main textbook introduced in the course on which students and the teacher worked intensively. In addition, other reading materials were used in the experimental group in order to provide opportunities for extensive reading. These books, mainly short stories, are entitled:

Carroll, Lewis, (2000), Alice's Adventures in Wonderland, level 2, Pearson Education Limited

Bassett, Jenifer, (2002) One-Way Ticket, level 1, Oxford Bookworm Collection

Pullman, Philip, (2000), Aladdin and the Enchanted Man, level 2, Oxford University Press

Wilde, Oscar, (2003), The Coldest Place on Earth, level 2, Oxford University Press

Tense, Walker, (2001) The Elephant Man, level 1, Oxford University Press

Moreover, this experimental study also took advantage of a pretest in order to make sure that participants were equal before treatment. It also used a recorder to record students' performance on the observation session for further analysis.

\section{Procedure}

To conduct the study, the participants were randomly assigned to each group to provide for control of the equivalence of experimental and control groups and exposure to treatment. The participants in the experimental group were encouraged to read large quantity of reading materials extensively along with the main reading textbook which was taught intensively by the teacher. The reading materials provided for extensive reading were mainly short stories whose difficulty levels were a little above the students' competence in order to provide comprehensible input. While the participants in the experimental group received the treatment, the students in the control group followed the usual procure studying the main course book intensively. 
At the end of the treatment, a post test which was based on the student oral performance was administered to both groups and observation of their performances were recorded for analysis. Each participant was asked to present a summary of a story orally and was given a score on a scale of 1 to 5 indicating the degree of accurate pronunciation, with 1 indicating that the student's presentation had more than 20 pronunciation mistakes, 2 indicating 15-20 mistakes, 3 indicating 10-15 mistakes, 4 indicating 5-10 mistakes and 5 indicating that the presentation had fewer than 5 mistakes. In this experiment which was based on treatment-non treatment comparison, observations were made to determine what differences appears or what change or modification occurs in the experimental group as contrasted with the control group.

\section{Design}

In order to have a comprehensive view of the research findings, this study implemented a mixed method approach, applying qualitative and quantitative procedures in conducting the experiment and reporting the results. As Zoltan Dornyei (2007) maintain "in most educational settings random assignment of students by the researcher is rarely possible" therefore we have to resort to a Quasi-experiment design. The pretest-post test equivalent-groups design provides the advantage of pretesting before the application of experimental and control treatments and post test at the end of the treatments. Pretests scores were used in the analysis of covariance to statistically control for any differences between the groups at the beginning of the study.

\section{DATA ANALYSIS}

Data analysis was the most challenging section of this study as far as multiple analyses were required. To this end, the data gathered from the students observations and records were coded and inserted into SPSS software 16.0 for analyzing. Both descriptive and inferential statistics were run. Descriptive and inferential statistics included frequency, percentage, mean, standard deviation and t-test.

\section{Results and discussions}

\section{Descriptive studies}

The aim of the question raised in this study was to investigate if the introduction of an extensive reading course has any impact on the learners' pronunciation ability. The investigation of this question was followed through descriptive statistics such as percentage and frequency. As mentioned earlier, the participants were a given a score on a rating scale of 1 to 5 based on their presentation performances on the post test. In order to make sure about the rating consistency and reliability, each score was specifically defined with 1 indicating more than 20 pronunciation mistakes, 2 indicating between 15 to 20 pronunciation mistakes, 3 indicating between 10 to 15 pronunciation mistakes, 4 indicating between 5 to 10 pronunciation mistakes and 5 indicating fewer than 5 pronunciation mistakes.

Table 1 displays the frequencies and percentages of the number of pronunciation mistakes in the students' presentations in both experimental and control groups.

TABLE 1:

FREQUENCIES AND PERCENTAGES OF STUDENTS' SCORES IN THE EXPERIMENTAL AND CONTROL GROUP

\begin{tabular}{|c|c|c|c|c|c|c|c|}
\hline & \multicolumn{5}{|c|}{ Scores } & \multirow[t]{2}{*}{ Total } \\
\hline & & 1 & 2 & 3 & 4 & 5 & \\
\hline \multirow[t]{2}{*}{ Experimental group } & $\mathrm{N}$ & 12 & 15 & 11 & 7 & 5 & 50 \\
\hline & $\%$ & $24 \%$ & $30 \%$ & $22 \%$ & $14 \%$ & $10 \%$ & $100 \%$ \\
\hline \multirow[t]{2}{*}{ Control Group } & $\mathrm{N}$ & 4 & 5 & 10 & 17 & 14 & 50 \\
\hline & $\%$ & $8 \%$ & $10 \%$ & $20 \%$ & $34 \%$ & $28 \%$ & $100 \%$ \\
\hline
\end{tabular}

As shown in Table 1, 30 percent of students in the experimental group had between 15 to 20 pronunciation mistakes in their presentations and only 10 percent of them had fewer than 5 mistakes. On the contrary, 34 percent of students in the control group had 5-10 pronunciation mistakes and only 8 percent of them had more than 20 pronunciation mistakes.

Figure 1 demonstrates the percentages of the students' pronunciation mistakes in both experimental and control groups.

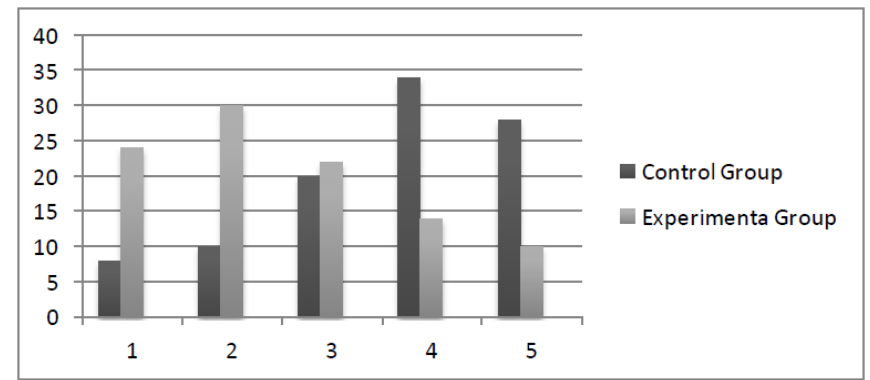

Figure 1: Frequencies and Percentages of Students' Scores in the Experimental and Control Group 
As it is demonstrated, it can be expressed that the students in the experimental group, who were encouraged to extensive reading in addition to intensive reading, had more pronunciation mistakes. While a total 30 percent of them had between 15-20 mistakes in their oral presentation recording, only 10 percent of the students in the control group had 15-20 pronunciation mistakes.

Table 2 summarizes the result of descriptive statistics. The mean score obtained from the two groups, shows that the individuals in experimental group had more difficulty in pronouncing the words correctly.

TABLE 2:

DESCRIPTIVE STATISTICS OF THE EXPERIMENTAL AND CONTROL GROUPS

\begin{tabular}{lcccc} 
Groups & $\mathrm{N}$ & Mean & Std. Deviation & Std. Error Mean \\
\hline Control & 50 & 3.20 & 1.26 & .1784 \\
Experimental & 50 & 2.54 & 1.32 & .1878
\end{tabular}

To ensure that the obtained difference is statistically significant, an independent-samples $t$-test was used. Table 2 shows that there was a statistically significant difference between the experimental group $(M=2.54, S D=1.32)$ and the control group $(M=3.20, S D=1.26), t(98)=2.54, p=.00$. Results suggest that introducing basic learners to extensive reading could be a predicator in wrong word pronouncing fossilization procedure. Learners in the control group reported to be more accurate in pronouncing the words than those in experimental groups.

TABLE3:

INFERENTIAL STATISTICS (RESULTS OF INDEPENDENT-SAMPLES T-TEST)

Independent Samples Test

\begin{tabular}{|c|c|c|c|c|c|c|c|c|c|}
\hline & \multicolumn{2}{|c|}{$\begin{array}{l}\text { Levene's Test for Equality } \\
\text { of Variances }\end{array}$} & \multicolumn{7}{|c|}{ t-test for Equality of Means } \\
\hline & \multirow[b]{2}{*}{$\mathrm{F}$} & \multirow[b]{2}{*}{ Sig. } & \multirow[b]{2}{*}{$\mathrm{t}$} & \multirow[b]{2}{*}{ df } & \multirow{2}{*}{$\begin{array}{l}\text { Sig. (2- } \\
\text { tailed) }\end{array}$} & \multirow{2}{*}{$\begin{array}{l}\text { Mean } \\
\text { Difference }\end{array}$} & \multirow{2}{*}{$\begin{array}{l}\text { Std. Error } \\
\text { Difference }\end{array}$} & \multicolumn{2}{|c|}{$\begin{array}{l}95 \% \text { Confidence Interval of } \\
\text { the Difference }\end{array}$} \\
\hline & & & & & & & & Lower & Upper \\
\hline $\begin{array}{l}\text { VAR00001 Equal variances } \\
\text { assumed } \\
\text { Equal variances not } \\
\text { assumed }\end{array}$ & .374 & .542 & $\begin{array}{l}2.548 \\
2.548\end{array}$ & $\begin{array}{l}98 \\
97.744\end{array}$ & $\begin{array}{l}.012 \\
.012\end{array}$ & $\begin{array}{l}.66000 \\
.66000\end{array}$ & $\begin{array}{l}.25906 \\
.25906\end{array}$ & $\begin{array}{l}.14591 \\
.14589\end{array}$ & $\begin{array}{l}1.17409 \\
1.17411\end{array}$ \\
\hline
\end{tabular}

\section{CONCLUSION}

As stated before, the aim of this study was to evaluate the effect of extensive reading on students' pronunciation mistakes. The results revealed that, in general, reading large quantity of materials extensively can lead in more pronunciation mistakes fossilization in students at low-levels of proficiency due to absence of instruction to ensure pronunciation accuracy. While countless advantages of using an extensive reading program in a language course have been outlined by different scholars, (Chao and Krashen (1994), Elley \& Mangubhai (1981), Pitts, White, \& Krashen, (1989)), reading large quantity of materials extensively can lead in fossilization of incorrect pronunciation mistakes, mainly due to absence of any instruction on the pronunciation accuracy. It can be inferred that, while students at low levels can improve their command of vocabulary, grammar and reading comprehension as a result of maximum exposure to large quantity of material consistent with their interests and motivation, they usually do nothing while faced with a new word whose pronunciation is not known by them. In other words, although students can use contextual clues successfully to guess the meaning of new word or to comprehend a sentence, they can not guess how a new word may be pronounced correctly. Eventually, this article paves the way for further analyses and researches about the role of extensive reading on learners' pronunciation at other levels of proficiency.

\section{REFERENCES}

[1] Brown, A. (1992). Twenty Questions. In A. Brown (Ed), Approaches to Pronunciation Teaching. London: Macmillan.

[2] Brumfit, C. J. (1978). The teaching of advanced reading skills in foreign languages, with particular reference to English as a foreign language. In V. Kinsella (Ed.), Language teaching and linguistics: Surveys (pp. 1 73-184). (Centre for Information on Language Teaching and Research and English Teaching Information Centre of the British Council. Cambridge: Cambridge University Press.

[3] Brumfit, C.J. (1979). Readers for foreign language learners of English (ETIC Information Guide 7). London: The British Council.

[4] Brumfit, C. (1984). Communicative methodology in language teaching: The roles of fluency and accuracy. Cambridge: Cambridge University Press

[5] Carrell, P.L., \& Carson, J.G. (1997). Extensive and Intensive Reading in an EAP Setting. English for Specific Purpose, 16,47-60.

[6] Cho, K., \& Krashen, S. D. (1994). Acquisition of vocabulary from the Sweet Valley Kids series: Adult ESL acquisition. Journal of Reading, 37, 662-667. 
[7] Coon, A., M. (2011). Grammar and Extensive Reading, The Modern Language Journal, Volume 16, Issue 1, 14-21

[8] Davis, C. (1995). ER: An Expensive Extravagence? ELT Journal, 49(4), 329-336.

[9] Day, R., \& Bamford, J. (1998). Extensive Reading in The Second Language Classroom. Cambridge: Cambridge University Press.

[10] Dubin, F., \& Olshtain, E. (1977). Facilitating language learning. New York: McGraw-Hill.

[11] Duffy, G. (1993). Teachers' progress toward becoming expert strategy teachers. Elementary School Journal, 94(2), 109-120.

[12] Dupuy, B., C. (1997). 'Voices from the classroom: intermediate-level French students favor extensive reading over grammar and give their reasons. Applied Language Learning, 285-93.

[13] Elley, W. B., \&Mangubhai, F. (1981). The Impact of A Book Flood In Fiji Primary Schools. Wellington: New Zealand Council for Educational Research.

[14] Grabe, William. (1995). Dilemmas for the development of second language reading abilities. Reprinted from Prospect, 10(2), $38-51$.

[15] Herbert, Julie. (1993). PracTESOL: It's not what you say, but how you say it.15-23.

[16] Krashen, S. (1993). The Power Of Reading: Insight from the Research. Englewood, CO: Libraries Unlimited.

[17] Nations, P. (1997). The Language Learning Benefits of Extensive Reading. Language Teacher, 21, 13-16.

[18] Pitts, M., White, H., \& Krashen, S. D. (1989). Acquiring Second Language Vocabulary through Reading: A Replication of the Clockwork Orange Study Using Second Language Acquirers. Reading in a Foreign Language, 5, 271-275.

[19] Renandya, W.A., \& Jacobs, G. M. (1999). Extensive Reading: Why Aren't we all Doing it? RELC Journal, 30(1).18-42.

[20] Richards, J. C. and Renandya, W.A. (2002). Methodology in language teaching, anthropology of current practice. Cambridge: Cambridge University Press.

[21] Robb, T. N., \& Susser, B. (1989). Extensive Reading vs. Skills Building in an EFL Context. Reading in a Foreign Language, Vol. 5, No. 2 (1989).35-66

[22] Swaffar, J.K. (1985). Reading authentic texts in a foreign language: A cognitive Model. The Modern Language Journal, 69, 15-34.

[23] Swaffar, J.K. (1988). Readers, texts, and second languages: The interactive processes. The Modern Language Journal, 72, 123149.

[24] Vaughan, J.L., Jr. (1982). Instructional strategies. In A. Berger \& H.A. Robinson (Eds.), Secondary school reading: What research reveals for classroom practice (pp. 67-84). Urbana, IL: ERIC Clearinghouse on Reading and Communications Skills and the National Conference on Research in English.

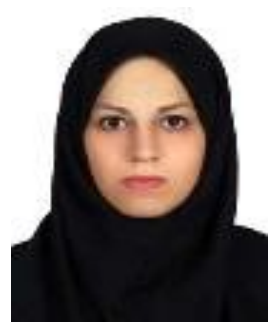

Elham Malmeer was born in Iran, has earned her MA in TEFL at Teharn University (South Branch), and now is a PhD. Candidate majoring TESL at Islamic Azad University, Ahar Branch in Iran.

She has been teaching English for about 9 years in different institutes and universities. Her main interest is testing and teaching English as a foreign language to Iranian learners. She is working on the Dynamic Assessment and its different applicability for Iranian language learners.

Seyed Mahdi Araghi $(\mathrm{PhD})$ was graduated from Panjab University, India, is an assistant professor in TEFL at Payam Noor University, (Tabriz), Iran. His research interests include psycholinguistics and applied linguistics. 